\title{
Yoga as an Exercise Prescription for the Pregnancy or Postpartum Period: Recent Advances and Perspective
}

\author{
Shujuan $\mathrm{Hu}^{1,2}$, Tao $\mathrm{Xu}^{2}$, Xianwang Wang ${ }^{3 *}$ \\ ${ }^{1}$ Institute of Education and Sports Sciences, Yangtze University, Jingzhou, China \\ ${ }^{2}$ Institute of Sport and Science, Jishou University, Jishou, China \\ ${ }^{3}$ Department of Biochemistry and Molecular Biology, Health Science Center, Yangtze University, Jingzhou, China \\ Email: 523254608@qq.com, 526888445@qq.com, *xwshine@yangtzeu.edu.cn
}

How to cite this paper: $\mathrm{Hu}, \mathrm{S}$.J., $\mathrm{Xu}, \mathrm{T}$. and Wang, X.W. (2021) Yoga as an Exercise Prescription for the Pregnancy or Postpartum Period: Recent Advances and Perspective. Yangtze Medicine, 5, 157-170. https://doi.org/10.4236/ym.2021.53016

Received: June 19, 2020

Accepted: September 12, 2021

Published: September 15, 2021

Copyright $\odot 2021$ by author(s) and Scientific Research Publishing Inc. This work is licensed under the Creative Commons Attribution International License (CC BY 4.0).

http://creativecommons.org/licenses/by/4.0/ (c) (i) Open Access

\begin{abstract}
The aim of this study is to examine studies published from 2015 to 2020 and to determine whether yoga can be an efficacious approach during the pregnancy or postpartum period. PubMed, EBSCO, Wiley and Science Direct databases were searched for studies published from January 2015 to June 2020. A total of 14 studies met the inclusion criteria, covering 1116 participants were identified. The results demonstrated that yoga intervention could significantly reduce depression $(\mathrm{P}<0.001)$, anxiety $(\mathrm{P}=0.003)$, labor pain $(\mathrm{P}=$ $0.001)$, back pain and the percentage of cesarean section $(P=0.002)$. There was significant improvement in psychological well-being $(\mathrm{P}<0.5)$, immune function and the intrauterine fetal growth $(\mathrm{P}<0.5)$. Moreover, the yoga intervention group has lower salivary cortisol $(\mathrm{P}<0.001)$, salivary alpha-amylase and salivary a-amylase levels $(\mathrm{P}<0.5)$ and higher immunoglobulin A $(\mathrm{P}<0.001)$ levels when compared with that in control groups. The findings suggested that yoga is well benefited for either pregnant women or postpartum women. More high-quality and well-controlled randomized controlled trials are required to provide more information regarding the utility of yoga interventions for different stages of pregnancy women.
\end{abstract}

\section{Keywords}

Yoga Intervention, Pregnancy, Postpartum, Psychological Well-Being

\section{Introduction}

A woman during pregnancy undergoes different physiological, psychological, social and emotional challenges [1]. It is indicated that stress and anxiety were 
occurred frequently during pregnancy and postpartum period of pregnancy, which contributes significantly to prematurity, low birth weight [2] and unplanned cesareans [3]. There are many therapeutic schemes for the discomfort of pregnant women, mainly including pharmaceutical drugs treatments and non-pharmacological treatments. However, pharmaceutical drugs may be harmful for the fetus, including the risks of side effects and substance dependence. To be specific, in the first and late trimester of pregnancy, inappropriate administration of the drugs can lead to malformation of the fetus. Therefore, non-pharmacological treatments have attracted more attention from researchers in recent years. It is widely acknowledged that mindfulness meditation [4], relaxation therapy [5], music [6], tai chi [7], qigong [8] and yoga [4] [7] could relieve the unpleasant symptoms of pregnant women.

Yoga has drawn more and more attention because it has plentiful forms and the essence of yoga is the coming together of mind, body and spirit, as well as the combination of postures, controlled breathing, meditation and relaxation [9] [10]. Yoga is a popular health practice for a variety of immunological, neuromuscular, psychological, and pain conditions in developed nations [11] [12]. Yoga has been shown to play crucial roles in ameliorating a variety of physical and psychological health conditions, involving anxiety, depression, metabolic syndrome, cancer, and cardiovascular, musculoskeletal, and pulmonary disorders [13] [14]. Cumulating studies have been demonstrated that prenatal yoga can improve the quality of sleep [9], infant and maternal outcomes [15], immune function [16], birth weight [15], maternal comfort during labor [17], as well as remission of low-back pain [18], depression, stress [16], anxiety [19] pregnancy-induced hypertension [15], refractory epilepsy [20], labor duration and anesthesia requirements [15] [17]. Nevertheless, there are not standard procedures for practicing yoga in pregnancy. In particular, there is an urgent need to determine which form of yoga is suitable for what kinds of pregnant women or different stages of pregnancy.

In the present study, the latest evidences that yoga could improve the physical and psychological symptoms of women during the prenatal or postpartum period of pregnancy were summarized.

\section{Methods and Materials}

To be included in the present study the articles have to meet the following criteria: 1) Was published in the English language. 2) Was included in the following databases: EBSCO, PubMed, Wiley and Science Direct online. 3) Was published between January 2015 and June 2020. 4) Was included any form of yoga as an intervention. 5) Was conducted during the prenatal or postpartum period of pregnancy. 6) Were full text clinical studies.

With use of the term (yoga or yogic) and the term (pregnancy or pregnant or prenatal or postnatal or postpartum), 343 articles were selected: 101 from EBSCO, 95 from PubMed, 49 from Wiley, 98 from Science Direct. We included randomized controlled trials (RCTs) that specifically stated that the intervention 
was yoga or yoga-based exercise during pregnancy or the postnatal period. We excluded 329 articles for the following reasons: not during pregnancy or postpartum, review, non-English, not a clinical study, no abstract available, no yoga intervention, no postures and reduplicative. Finally, the remaining articles $(\mathrm{N}=$ 14) satisfied the eligibility criteria (As shown in Figure 1).

\section{Results}

\subsection{Characteristics of the Included Trials}

In this study, 14 trials published between 2015 and 2020 were selected for final analysis. Four studies were originated from the United States [21] [22] [23] [24], three from Japan [25] [26] [27], one each from India [28], Taiwan [29], UK [30], Turkey [31], Iran [32] [33], and Indonesia [34]. As shown in Table 1, the characteristics of the included studies were summarized. Randomized controlled design was used in ten of fourteen studies, single-blind experiment method was used in two studies, pre-test/post-test designs were applied in one trail. Participants included healthy pregnancy and high-risk pregnant women, with their mean ages ranging from 18 to 45 years. Among them, one study was high-risk pregnant woman, two studies were postpartum women, and five of the subjects were primiparous women. Specifically, participants in three studies experienced symptoms of depression and anxiety, and in two studies experienced labor pains during pregnancy. However, majority of studies have been done for healthy pregnant women. Moreover, most of these researches reported measurements which made with scaling method and questionnaire, and three studies reported measurements made with saliva samples [26] [27] [29] and blood samples [26]. In addition, the sample size is small in most studies, except the sample size of one study over 100 participants. In fact, the sample size directly or indirectly affects the results of the experiment.

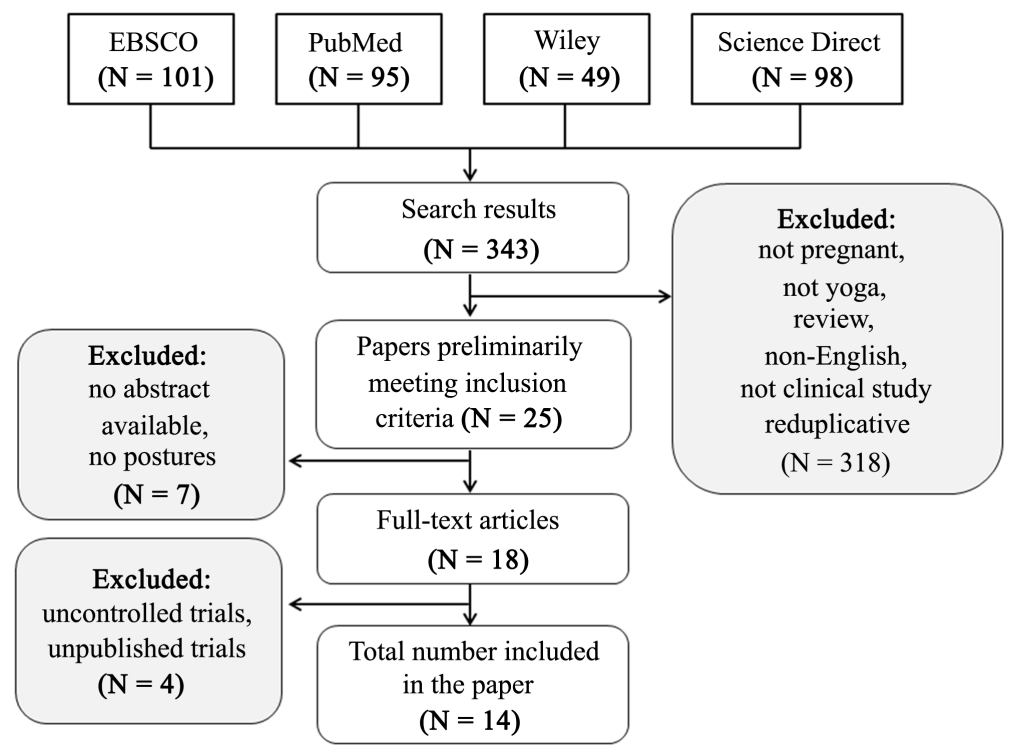

Figure 1. The process of literatures screening. 
Table 1. The controlled studies of yoga for pregnancy.

\begin{tabular}{|c|c|c|c|c|c|c|}
\hline $\begin{array}{c}\text { Authors } \\
\text { (year, country) }\end{array}$ & $\begin{array}{l}\text { Study } \\
\text { design }\end{array}$ & $\begin{array}{l}\text { Sample size } \\
\text { and } \\
\text { population }\end{array}$ & $\begin{array}{l}\text { Yoga and } \\
\text { comparison }\end{array}$ & $\begin{array}{l}\text { Outcomes } \\
\text { measured }\end{array}$ & $\begin{array}{l}\text { Results and } \\
\text { conclusions }\end{array}$ & $\begin{array}{l}\text { limited and } \\
\text { Development } \\
\text { trend }\end{array}$ \\
\hline $\begin{array}{c}\text { Buttner } \\
\text { M. M. et al. } \\
(2015, \text { USA) }\end{array}$ & RCT & $\begin{array}{l}\mathrm{N}=57 \\
\text { (28 Yoga, } \\
29 \text { Control; } \\
\text { Postpartum) }\end{array}$ & $\begin{array}{l}8 \mathrm{wk}(1 \mathrm{~h}, 1 / \mathrm{wk}) \\
(8 \mathrm{hr}) \text { Control: } \\
\text { Wait-list control }\end{array}$ & $\begin{array}{l}\text { PHQ-9 SCID-I } \\
\text { HDRS 5-point } \\
\text { Likert scale }\end{array}$ & $\begin{array}{l}\text { Depressive } \\
\text { symptoms } \\
\text { decreased } \\
(\mathrm{P}<0.001) \\
\text { in yoga group. }\end{array}$ & $\begin{array}{l}\text { 1) The sample } \\
\text { size was small. } \\
\text { 2) Did not provide } \\
\text { "suboptimal" } \\
\text { therapy of } \\
\text { another type. }\end{array}$ \\
\hline $\begin{array}{l}\text { Rakhshani A. } \\
\text { et al. } \\
\text { (2015, India) }\end{array}$ & RCT & $\begin{array}{l}\mathrm{N}=59 \\
(27 \text { Yoga, } \\
32 \text { Control; } \\
\text { High-risk } \\
\text { pregnancy, } \\
12-28 \mathrm{WG})\end{array}$ & $\begin{array}{l}28 \text { sessions } \\
(1 \mathrm{~h}, 3 / \mathrm{wk}) \\
(28 \mathrm{hr}) \\
\text { Control: Standard } \\
\text { care plus walking }\end{array}$ & $\begin{array}{l}\text { ANOVA } \\
\text { SPSS T-test } \\
\text { Chi-Square test }\end{array}$ & $\begin{array}{l}\text { Yoga can improve } \\
\text { the intrauterine fetal } \\
\text { growth and the } \\
\text { utero-fetal-placental } \\
\text { circulation. }\end{array}$ & $\begin{array}{l}\text { 1) The sample } \\
\text { size was small. } \\
\text { 2) It was not able } \\
\text { to collect all the } \\
\text { necessary data } \\
\text { required. }\end{array}$ \\
\hline $\begin{array}{c}\text { Davis K. } \\
\text { et al. } \\
(2015, \text { USA) }\end{array}$ & RCT & $\begin{array}{l}\mathrm{N}=46 \\
\text { (23 Yoga, } \\
23 \text { Control; } \\
\text { up to } 28 \mathrm{WG} \\
\text { with symptoms } \\
\text { of depression } \\
\text { and anxiety) }\end{array}$ & $\begin{array}{l}8 \mathrm{wk} \\
(75 \mathrm{~min}, 1 / \mathrm{wk}) \\
(10 \mathrm{hr}) \\
\text { Control: } \\
\text { Treatment } \\
\text { as usual }\end{array}$ & $\begin{array}{l}\text { EPDS } \\
\text { STAI } \\
\text { IPAQ } \\
\text { CSQ-8 }\end{array}$ & $\begin{array}{l}\text { 1) Yoga was reduced } \\
\text { in negative affect as } \\
\text { compared to TAU } \\
(\mathrm{P}=0.011) \text {. } \\
\text { 2) Depression and } \\
\text { anxiety were reduced } \\
\text { during the yoga } \\
\text { intervention. }\end{array}$ & $\begin{array}{l}\text { The control } \\
\text { group was } \\
\text { heterogeneous } \\
\text { in nature and } \\
\text { unrestrictive. }\end{array}$ \\
\hline $\begin{array}{l}\text { Uebelacker } \\
\text { L. A. et al. } \\
(2015, \text { USA) }\end{array}$ & RCT & $\begin{array}{l}\mathrm{N}=20 \\
\text { (12 Yoga, } \\
8 \text { Control; } \\
12 \text { - 26 WG) }\end{array}$ & $\begin{array}{l}9 \mathrm{wk} \\
(75 \mathrm{~min}, 1 / \mathrm{wk}) \\
(11.25 \mathrm{hr}) \\
\text { Control: Focused } \\
\text { on mother's and } \\
\text { baby's health }\end{array}$ & $\begin{array}{l}\text { QIDS } \\
\text { Questionnaire } \\
\text { CSQ-8 SCID } \\
\text { EPDS }\end{array}$ & $\begin{array}{l}\text { Prenatal yoga could } \\
\text { be helpful for women } \\
\text { with mild to } \\
\text { moderate levels } \\
\text { of depression. }\end{array}$ & $\begin{array}{l}\text { Further } \\
\text { investigation was } \\
\text { warranted to } \\
\text { evaluate whether } \\
\text { prenatal yoga } \\
\text { could represent an } \\
\text { effective } \\
\text { intervention for } \\
\text { mild moderate } \\
\text { antenatal } \\
\text { depression. }\end{array}$ \\
\hline $\begin{array}{c}\text { Kusaka M. } \\
\text { et al. } \\
\text { (2016, Japan) }\end{array}$ & Pre-post test & $\begin{array}{l}\text { time } 1, N=53 \\
\text { time } 2, N=46 \\
(18-22 W G)\end{array}$ & $\begin{array}{l}8 \text { - } 9 \text { sessions } \\
(1 \mathrm{~h}, 2 / \text { month }) \\
\text { (9 hr) Control: } \\
\text { Pre-post test }\end{array}$ & $\begin{array}{l}\text { Questionnaire } \\
\text { survey EIA } \\
\text { POMS-65 SPSS }\end{array}$ & $\begin{array}{l}\text { 1) The mean salivary } \\
\text { cortisol concentration } \\
\text { declined after each } \\
\text { yoga class }(\mathrm{P}=0.001) \text {. } \\
\text { 2) The mean salivary } \\
\text { a-amylase } \\
\text { concentration } \\
\text { decreased }(\mathrm{P}=0.001) \text {. }\end{array}$ & $\begin{array}{l}\text { 1) Single object } \\
\text { 2) It was not clear } \\
\text { which component } \\
\text { reduced stress. } \\
\text { 3) The frequency } \\
\text { of yoga practice } \\
\text { was widely } \\
\text { different. }\end{array}$ \\
\hline $\begin{array}{c}\text { Timlin D. et al. } \\
(2017, \mathrm{UK})\end{array}$ & RCT & $\begin{array}{l}\mathrm{N}=32 \\
\text { (16 Yoga, } \\
16 \text { Control; } \\
6 \text { months to } \\
1 \text { year } \\
\text { postpartum) }\end{array}$ & $\begin{array}{l}4 \mathrm{wk}(1 \mathrm{~h}, 1 / \mathrm{wk}) \\
(4 \mathrm{hr}) \text { Control: } \\
\text { Not receive an } \\
\text { intervention }\end{array}$ & $\begin{array}{l}\text { PAR-Q } \\
\text { ANOVA } \\
\text { PANAS }\end{array}$ & $\begin{array}{l}\text { The yoga group had } \\
\text { improved } \\
\text { psychological well-being } \\
\text { as indicated by } \\
\text { reductions in stress, } \\
\text { negative affect, and } \\
\text { dysfunctional } \\
\text { coping and increases } \\
\text { in problem focused } \\
\text { coping at follow up } \\
(\mathrm{P}<0.05) \text {. }\end{array}$ & $\begin{array}{l}\text { 1) The sample } \\
\text { size was small. } \\
\text { 2) Single object. }\end{array}$ \\
\hline
\end{tabular}




\section{Continued}

\begin{tabular}{|c|c|c|c|c|c|c|}
\hline $\begin{array}{c}\text { Matsuzaki M. } \\
\text { et al. } \\
\text { (2017, Japan) }\end{array}$ & RCT & $\begin{array}{l}\mathrm{N}=400 \\
(100 \text { Yoga, } 100 \\
\text { Nutritional } \\
\text { guidance, } 100 \\
\text { yoga and } \\
\text { nutritional } \\
\text { guidance, } 100 \\
\text { Standard care; } \\
18-23 \mathrm{WG})\end{array}$ & $\begin{array}{l}20 \mathrm{wk}(1 \mathrm{~h}, 3 / \mathrm{wk}) \\
(60 \mathrm{hr}) \\
\text { Control: } \\
\text { Standard } \\
\text { care alone }\end{array}$ & $\begin{array}{l}\text { Questionnaire } \\
\text { SPSS Blood } \\
\text { samples Saliva } \\
\text { samples BDHQ }\end{array}$ & $\begin{array}{l}\text { 1) Pregnant women } \\
\text { with gestational } \\
\text { weight gain. } \\
\text { 2) Yoga exercise and } \\
\text { nutritional } \\
\text { intervention } \\
\text { are useful for } \\
\text { healthcare providers } \\
\text { and pregnant women. }\end{array}$ & $\begin{array}{l}\text { 1) Cannot clarify } \\
\text { what aspect of } \\
\text { yoga exercise } \\
\text { causes its impact. } \\
\text { 2) A dietary } \\
\text { assessment } \\
\text { questionnaire can } \\
\text { induce recall bias } \\
\text { and reporting bias. }\end{array}$ \\
\hline $\begin{array}{l}\text { Chen P.J. et al. } \\
\text { (2017, Taiwan) }\end{array}$ & RCT & $\begin{array}{l}\mathrm{N}=94 \\
(48 \text { yoga, } \\
46 \text { control; } \\
16 \text { - } 36 \mathrm{WG})\end{array}$ & $\begin{array}{l}20 \mathrm{wk} \\
(70 \mathrm{~min}, 2 / \mathrm{wk}) \\
(46 \mathrm{hr}) \text { Control: } \\
\text { Receiving routine } \\
\text { prenatal care }\end{array}$ & $\begin{array}{l}\text { Saliva samples } \\
\text { SPSS }\end{array}$ & $\begin{array}{l}\text { 1) The yoga group had } \\
\text { lower salivary cortisol } \\
(\mathrm{P}<0.001) \text { and higher } \\
\text { immunoglobulin A } \\
(\mathrm{P}<0.001) \text { levels. } \\
\text { 2) The yoga group } \\
\text { had higher long-term } \\
\text { salivary } \\
\text { immunoglobulin A } \\
\text { levels }(\mathrm{P}=0.018) \text {, } \\
\text { weighed more than } \\
\text { those born to the } \\
\text { control group } \\
(\mathrm{P}<0.001) .\end{array}$ & $\begin{array}{l}\text { 1) The impact of } \\
\text { yoga on long-term } \\
\text { outcomes and } \\
\text { other physiological } \\
\text { indicators of } \\
\text { immune and } \\
\text { adrenal function } \\
\text { were not } \\
\text { measured. } \\
\text { 2) The dose and } \\
\text { frequency of yoga } \\
\text { may not have been } \\
\text { enough to produce } \\
\text { long-term effects } \\
\text { on salivary } \\
\text { cortisol levels. }\end{array}$ \\
\hline $\begin{array}{l}\text { Jahdi F. et al. } \\
\text { (2017, Iran) }\end{array}$ & $\begin{array}{c}\text { RCT } \\
\text { (single-blind) }\end{array}$ & $\begin{array}{l}\mathrm{N}=60 \\
(30 \text { Yoga, } 30 \\
\text { Control; } \\
18 \text { - } 35 \text { years } \\
\text { old Primiprous; } \\
26 \text { - } 37 \text { WG) }\end{array}$ & $\begin{array}{l}12 \mathrm{wk}(1 \mathrm{~h}, 3 / \mathrm{wk}) \\
(36 \mathrm{hr}) \text { Control: } \\
\text { Received routine } \\
\text { care }\end{array}$ & $\begin{array}{l}\text { VAS SPSS } \\
\text { Apgar Score }\end{array}$ & $\begin{array}{l}\text { 1) Yoga class required } \\
\text { a decreased frequency } \\
\text { of labor induction } \\
(\mathrm{P}=0.008) \text {. } \\
\text { 2) Delivery of the yoga } \\
\text { group resulted in a lower } \\
\text { percentage of cesarean } \\
\text { section }(\mathrm{P}=0.002) . \\
\text { 3) Control group } \\
\text { reported higher pain } \\
\text { intensity }(\mathrm{P}=0.01) .\end{array}$ & $\begin{array}{l}\text { 1) Do more } \\
\text { investigation on } \\
\text { the effects of yoga } \\
\text { exercises on } \\
\text { different } \\
\text { pregnancy } \\
\text { consequences } \\
\text { and delivery } \\
\text { procedures. } \\
\text { 2) More research } \\
\text { on mental } \\
\text { processes. }\end{array}$ \\
\hline $\begin{array}{c}\text { Hayase M. } \\
\text { et al. } \\
\text { (2018, Japan) }\end{array}$ & Questionnaires & $\begin{array}{l}\mathrm{N}=91 \\
\text { (38 Yoga, } \\
53 \text { Control; } \\
20 \text { - } 23 \mathrm{WG} \\
\text { and continued } \\
\text { until delivery) }\end{array}$ & $\begin{array}{l}18 \mathrm{wk}(1 \mathrm{~h}, 1 / \mathrm{wk}) \\
(18 \mathrm{hr}) \text { Control: } \\
\text { Not attend the } \\
\text { yoga classes }\end{array}$ & $\begin{array}{l}\text { HR variability } \\
\text { monitor Saliva } \\
\text { samples } \\
\text { Questionnaire } \\
\text { PSS }\end{array}$ & $\begin{array}{l}\text { 1) Yoga activates the } \\
\text { parasympathetic } \\
\text { nervous system during } \\
\text { the third trimester } \\
\text { of pregnancy. } \\
\text { 2) Consolidating sleep } \\
\text { during the night } \\
\text { 3) Decreasing } \alpha \text {-amylase } \\
\text { levels and stress. }\end{array}$ & $\begin{array}{l}\text { 1) Small sample } \\
\text { size. } \\
\text { 2) The study } \\
\text { population was } \\
\text { not sufficient to } \\
\text { fully investigate. }\end{array}$ \\
\hline $\begin{array}{c}\text { Akarsu R.H. } \\
\text { et al. } \\
\text { (2018, Turkey) }\end{array}$ & RCT & $\begin{array}{l}\mathrm{N}=63 \\
\text { (31 Yoga, } \\
32 \text { Control; } \\
\text { Primiprous; } \\
14 \text { - 26 WG) }\end{array}$ & $\begin{array}{l}8 \mathrm{wk} \\
(40 \mathrm{~min}, 2 / \mathrm{wk}) \\
(10.5 \mathrm{hr}) \text { Control: } \\
\text { Received routine } \\
\text { antenatal care. }\end{array}$ & $\begin{array}{l}\text { PIF PPHAS PAI } \\
\text { SPSS }\end{array}$ & $\begin{array}{l}\text { 1) The mean pregnancy } \\
\text { psychosocial Health } \\
\text { Assessment scale scores } \\
\text { of the yoga group were } \\
\text { higher }(\mathrm{P}<0.001) \text {. } \\
\text { 2) The prenatal } \\
\text { attachment inventory } \\
\text { mean scores and the } \\
\text { anxiety and stress scores } \\
\text { of the yoga group were } \\
\text { higher }(\mathrm{P}<0.05) \text {. }\end{array}$ & $\begin{array}{l}\text { Further research } \\
\text { is needed using } \\
\text { larger sample of } \\
\text { pregnant women } \\
\text { with different } \\
\text { education levels. }\end{array}$ \\
\hline
\end{tabular}




\section{Continued}

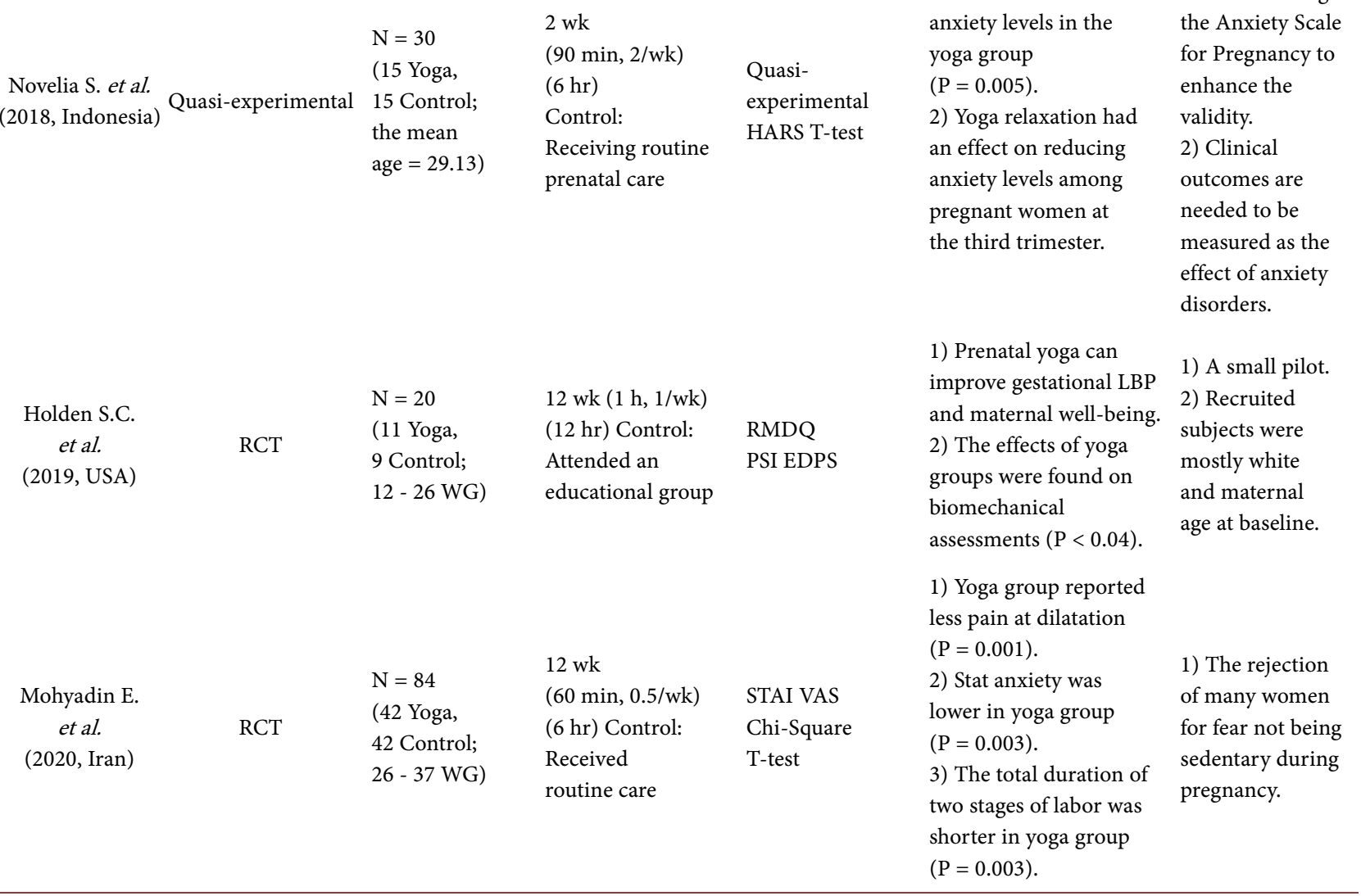

Abbreviations: $\mathrm{wk}$ = week; $\mathrm{hr}=$ hour; WG = Week of Gestation; PHQ-9 = 9-item Patient Health Questionnaire; SCID-I = Structured Clinical Interview for DSM-IV Axis-I Disorders; HDRS = Hamilton Depression Rating Scale; RM-ANOVA = Repeated Measures ANOVA; SPSS = Statistical Product and Service Solutions; EPDS = Edinburgh Postnatal Depression Scale; STAI = State-Trait Anxiety Inventory; IPAQ = International Physical Activity Questionnaire; CSQ-8 = Client Satisfaction Questionnaire-8; QIDS = Quick Inventory of Depressive Symptomatology; EIA = Salivary Enzyme Immunoassay; PAR-Q = Physical Activity Readiness Questionnaire; ANOVA $=$ Analysis of Variance; PANAS $=$ Positive and Negative Affect Schedules; BDHQ $=$ Brief-type Diet History Questionnaire; VAS = Visual Analogue Scale; PSS = Perceived Stress Scale; PIF = Pregnant Information Form; PPHAS = Pregnant Psychosocial Health Assessment Scale; PAI = Prenatal Attachment Inventory; HARS = Hamilton Anxiety Rating Scale; RMDQ = Roland Morris Disability Questionnaire; PSI = Pregnancy Symptom Inventory; HRQOL $=$ Health Related Quality of life; TAU = Treatment as usual; POMS $=$ Profiles of Mood states.

As shown in Table 1, these researchers found that the yoga group was more effective at reducing depression, frequency of labor induction and stress than that in the routine care group $(\mathrm{P}<0.01)$. Although Davis (2015) found no evidence of greater decline in depression or anxiety for either the yoga group or the routine care group, the practitioners favored yoga [22]. Two studies found that the yoga group improved psychological well-being, decreased $\alpha$-amylase levels and reduced stress when compared with those in the non-yoga groups $(\mathrm{P}<0.05)$ [27] [30]. Lisa et al. (2015) compared the yoga group with the group focused on mother's and baby's health and found that yoga practice was more effective in reducing depression $(\mathrm{P}<0.05)$ [23]. What's more, control interventions for some studies included a walking group [28] and an educational support group [24]. 


\subsection{Yoga Intervention Program}

Four different types of yoga were included in these researches: Dru yoga, Hatha yoga, Prenatal yoga and Ashtanga yoga. Dru yoga was origin from Hatha yoga and included classical yoga postures, pranayama, mudra (hand gestures) and positive affirmations, empowering visualizations and sequences, performing in a flowing, gentle style [30]. Ashtanga yoga is the traditional Ashtanga Vinyasa system of yoga, which relieves the symptom of depressed and anxiety [21] [30]. However, most of these researches used Hatha yoga and prenatal yoga, including yoga postures, breathing, meditation and relaxation. Most of the yoga interventions in the included studies were ranged from 40 to 75 minutes, 1 to 3 times per week. Most of studies provided participants with materials, including cassettes, booklets, and DVDs, which guide them to practice at home 1 to 3 times per week.

Moreover, many trials have been provided the list of postures, which were used in the yoga intervention (see Table 2). The various components of yoga practice process that were included in the reviewed trials, involving postures (Asana), breathing practices (Pranayama), concentration/meditation (Dharana/Dhyana), deep relaxation (Yoga Nidra), mudra (Hand Gestures), Guided imagery and Chanting. Among them, yoga postures were included in all the reviewed researches. Breathing practices were applied in most of the yoga interventions. However, meditation and deep relaxation were excluded in some studies. Only minority of studies have been applied chanting [32], hand gestures [30] and guided imagery [28] [29]. In fact, the complete pregnancy yoga class should include the most important elements such as meditation, breathing, postures and relaxation [35]. In addition, the maternity yoga class was recommended at least 60 minutes at a time, 2 - 3 times a week, for 8 weeks or more for better pregnancy improvement.

\subsection{Outcome Measurement}

Outcomes measurements in the present study included psychological well-being, pregnancy-related pain, birth outcomes and so on.

\subsubsection{Effect of Yoga on Psychological Well-Being}

The results showed that yoga intervention is positively correlated with psychological well-being. Studies suggested that yoga can be effective for enhancing psychological well-being [30] [36] and increasing confidence [37] by reductions in stress, negative affect $(\mathrm{P}=0.011)$ [22] [30], and dysfunctional coping $(\mathrm{P}<$ $0.05)$ in the perinatal and postnatal period [30]. Eight studies used the psychological-related scales to assess the effects of yoga on mood and quality of life during and after perinatal period. For example, Rukiye et al. (2018) showed that the scores of the mean pregnancy psychosocial health assessment scale $(\mathrm{P}<$ 0.001) of the yoga group were higher than those of the control group $(\mathrm{P}<0.05)$ [31]. The scores of the mean pregnancy psychosocial health assessment scale can effectively reflect the level of psychological well-being.

In addition, negative psychological effects of pregnancy include depression, stress, anxiety and so on. Many pregnant women experience prenatal or 
Table 2. The components of yoga intervention for each study.

\begin{tabular}{|c|c|c|c|c|c|c|c|}
\hline \multirow[b]{2}{*}{$\begin{array}{c}\text { Authors } \\
\text { (year, country) }\end{array}$} & \multicolumn{7}{|c|}{ Components of yoga intervention } \\
\hline & $\begin{array}{l}\text { Postures } \\
\text { (Asana) }\end{array}$ & $\begin{array}{l}\text { Breathing } \\
\text { (Pranayama) }\end{array}$ & $\begin{array}{l}\text { Meditation } \\
\text { (Dharana) }\end{array}$ & $\begin{array}{l}\text { Relaxation } \\
\text { (Nidra) }\end{array}$ & Chanting & $\begin{array}{l}\text { Mudra } \\
\text { (Hand } \\
\text { gestures) }\end{array}$ & $\begin{array}{l}\text { Guided } \\
\text { imagery }\end{array}$ \\
\hline $\begin{array}{l}\text { Buttner M. M. } \\
\text { et al. }(2015, \text { USA) }\end{array}$ & $\sqrt{ }$ & & & $\sqrt{ }$ & & & \\
\hline $\begin{array}{l}\text { Rakhshani A. et al. } \\
\text { (2015, India) }\end{array}$ & $\sqrt{ }$ & $\sqrt{ }$ & & $\sqrt{ }$ & & & $\sqrt{ }$ \\
\hline $\begin{array}{c}\text { Davis K. et al. } \\
(2015 \text {, USA) }\end{array}$ & $\sqrt{ }$ & $\sqrt{ }$ & & & & & \\
\hline $\begin{array}{l}\text { Uebelacker L. A. } \\
\text { et al. }(2015, \text { USA) }\end{array}$ & $\sqrt{ }$ & $\sqrt{ }$ & $\sqrt{ }$ & & & & \\
\hline $\begin{array}{l}\text { Kusaka M. et al. } \\
\text { (2016, Japan) }\end{array}$ & $\sqrt{ }$ & $\sqrt{ }$ & $\sqrt{ }$ & & & & \\
\hline $\begin{array}{l}\text { Timlin D. et al. } \\
(2017, \text { UK) }\end{array}$ & $\sqrt{ }$ & $\sqrt{ }$ & & & & $\sqrt{ }$ & \\
\hline $\begin{array}{l}\text { Matsuzaki M. et al. } \\
\text { (2017, Japan) }\end{array}$ & $\sqrt{ }$ & $\sqrt{ }$ & $\sqrt{ }$ & & & & \\
\hline $\begin{array}{l}\text { Chen P. J. et al. } \\
\text { (2017, Taiwan) }\end{array}$ & $\sqrt{ }$ & $\sqrt{ }$ & & $\sqrt{ }$ & & & $\sqrt{ }$ \\
\hline $\begin{array}{l}\text { Jahdi F. et al. } \\
\text { (2017, Iran) }\end{array}$ & $\sqrt{ }$ & $\sqrt{ }$ & $\sqrt{ }$ & $\sqrt{ }$ & $\sqrt{ }$ & & \\
\hline $\begin{array}{l}\text { Hayase M. et al. } \\
\text { (2018, Japan) }\end{array}$ & $\sqrt{ }$ & $\sqrt{ }$ & $\sqrt{ }$ & & & & \\
\hline $\begin{array}{c}\text { Akarsu R. H. et al. } \\
\text { (2018, Turkey) }\end{array}$ & $\sqrt{ }$ & $\sqrt{ }$ & $\sqrt{ }$ & $\sqrt{ }$ & & & \\
\hline $\begin{array}{l}\text { Novelia S. et al. } \\
(2018, \text { Indonesia) }\end{array}$ & $\sqrt{ }$ & $\sqrt{ }$ & $\sqrt{ }$ & & & & \\
\hline $\begin{array}{l}\text { Holden S. C. et al. } \\
\quad(2019, \text { USA })\end{array}$ & $\sqrt{ }$ & $\sqrt{ }$ & $\sqrt{ }$ & $\sqrt{ }$ & & & \\
\hline $\begin{array}{l}\text { Mohyadin E. et al. } \\
\quad(2020 \text {, Iran })\end{array}$ & $\sqrt{ }$ & $\sqrt{ }$ & $\sqrt{ }$ & & & & \\
\hline
\end{tabular}

postpartum depression, which is accompanied by anxiety and poor health-related quality of life [21] [38], affecting the physical and mental health of both mothers and fetus [39]. Five studies reported that alterations have been found in stress and depression symptoms after the yoga intervention. Yoga plays an important role in decreasing stress and depression symptoms [21] [23] [29] [40] of pregnant or postpartum women $(\mathrm{P}<0.001)$. Furthermore, Chen \& Momoko found that yoga intervention group demonstrated lower salivary cortisol $(P<0.001)$ [25] [29] and higher immunoglobulin A $(\mathrm{P}<0.001)$ levels than that in control group, because of the positive relationship between stress and cortisol levels [41].

Momoko \& Mako found the salivary alpha-amylase and salivary a-amylase (a biomarker of stress) levels were decreased significantly after yoga intervention $(\mathrm{P}<$ 
0.5) [25] [27]. Salivary a-amylase is often used as a non-invasive and alternative biomarker to norepinephrine [42]. Masayo et al. (2017) showed that the yoga intervention could reduce psychological stress and gain gestational weight when compared with that in control group [26]. Momoko et al. (2016) found that the scores for negative dimensions of mood (Trait-Anxiety, Depression, Anger-Hostility, Fatigue and Confusion) were decreased significantly in the yoga group [25]. The scores for negative dimensions of mood can reflect levels of stress, and the scores are negatively correlated with stress. Moreover, Melissa's study is the first efficacy trial of yoga for postpartum depression, and extends empirical support for yoga with postpartum women [21]. The women in the yoga group showed greater improvement in their mental health than those in the control group [21].

Maternal anxiety usually occurs during pregnancy and adversely affects maternal and infant health if inappropriate managed. Shinta et al. (2018) showed that there was a significant difference in the anxiety levels before and after the yoga intervention $(\mathrm{P}=0.005)$, as well as the groups between yoga and control. Ellahe et al. (2020) found that anxiety levels was lower in yoga group than that in control group $(\mathrm{P}=0.003)$. Yoga had an effect on reducing anxiety levels among pregnant women at the third trimester [34]. While most studies have shown that yoga to be useful for depression, one study found both of yoga group and control group reduced the severity of symptoms of depression and anxiety, but they found no evidence of greater decline in depression and anxiety either in yoga group or control group [22].

In a word, the negative psychological effects of depression, stress and anxiety during or after pregnancy will be reduced by yoga intervention.

\subsubsection{Effect of Yoga on Pregnancy-Related Pain}

Pregnancy-related pain is a serious health problem affecting a large majority of pregnant women [18]. During pregnancy, many women have experienced labor pain and low back pain, especially labor pain is unique and complex to each mother [43]. Yoga has been an effective non-pharmacological method to relieve labor pain ( $\mathrm{P}=0.001)$ [33] and back pain $(\mathrm{P}<0.05)$ [41] [44]. Fereshteh et al. (2017) found that yoga can reduce pain of labor, they also showed that prenatal yoga can reduce the percentage of cesarean section $(P=0.002)$, decrease the frequency of labor induction $(\mathrm{P}=0.008)$ and improve adequacy of childbirth during pregnancy [32]. However, Selma et al. (2019) showed that there was no significant difference in back pain between the yoga group and the control group [24].

Martins (2008) concluded that a weekly hour of Hatha yoga practice for 10 weeks can significantly reduce lower back and pelvic pain during pregnancy [17]. For pregnant women who were not in the habit of practicing yoga regularly, a yoga intervention which included one-time 20-minute yoga session significantly relieved leg and back pain [45].

\subsubsection{Effect of Yoga on the Labor Outcomes}

The labor outcomes directly affects pregnant women's mood. Chen et al. (2017) 
found that women in the yoga group gave birth to heavier babies than women in the control group ( $\mathrm{P}<0.001)$ [29]. In addition, Abbas et al. (2015) investigated the high-risk pregnancy women and found that yoga can improve the intrauterine fetal growth and the utero-fetal-placental circulation [28].

Fereshteh et al. (2017) showed there was no difference in birth weight in the yoga group during the first stage of labor $(\mathrm{P}>0.5)$, but the average duration of the second and third stages of labor was shorter than that in the control group $(\mathrm{P}<$ 0.05) [32].

Mako et al. (2018) showed the yoga group had longer night-time sleep duration and activated the parasympathetic nervous system than that in the control group [23].The immune function of maternal was significantly enhanced in the yoga intervention group when compared with that in control group [29]. The incidence of prenatal disorders was lower in the yoga group than that in the control group ( $<$ 0.05) [38]. Selma et al. (2019) found changes in the biomechanical assessments of pregnant women, including percentage change in gait speed $(\mathrm{P}<0.04)$, double support time $(\mathrm{P}<0.01)$, instrumented timed-up-and-go $(\mathrm{P}<0.01)$, and turn time $(\mathrm{P}<0.02)$ after yoga intervention [24].

\subsubsection{Effect of Yoga on Various Stages of Pregnancy}

One of studies for the first time is to target women in various stages of pregnancy for monitoring [27]. Mako et al. (2018) found the yoga group showed longer sleep times at 28 - 31 weeks, the sleep times are longer and the ratio of sleep at night is also higher at 36 - 40 weeks than that in the control group, but is not observed at 20 - 23 weeks' gestation [27]. One of studies is innovative to practice yoga from 16 to 36 weeks' gestation, it was longer time for pregnant women, but it was better visual observation, included the effect and the attention of yoga intervention [29].

What's more, Pont et al. (2019) found the effectiveness of prenatal yoga in reducing maternal discomfort at third trimester of pregnancy [46]. These studies were looking at the third trimester of pregnancy, because of this stage is important for both the pregnant woman and the fetus. In the third trimester of pregnancy, women should pay more attention to the intensity and time of exercise, to avoid fatigue, but also need appropriate exercise, conducive to natural childbirth.

\section{Conclusions and Prospection}

In conclusion, the findings showed that the pregnancy yoga was useful for either pregnant or postpartum women. The evidences suggested that yoga intervention could reduce depression, stress, anxiety, labor pain, back pain and the percentage of cesarean section during pregnancy. Moreover, yoga intervention will improve psychological well-being, immune function, quality of sleep and life, adequacy of childbirth, the intrauterine fetal growth and the utero-fetal-placental circulation during pregnancy. Overall, there is evidence that yoga is suitable for both pregnancy and postpartum women.

Additionally, these studies also have some limitations. Most of studies had small sample size, short time and single research object. In addition, there are no stan- 
dard programs for yoga practice in pregnancy and it is not clear what aspects of yoga cause its impact. Studies have confirmed that yoga interventions have an effect on pregnant women during pregnancy, but none of the studies have identified which components of yoga have an effect on women during pregnancy. Last but not least, the majority of studies were unable to collect all the necessary data because some participants did not complete the entire experiment.

In light of the limitations of existing research, we recommend that further randomized controlled trials are needed to provide more reliable evidence of the effectiveness and practicality of yoga interventions. The existing researches focused primarily on the effects of yoga intervention on the health of pregnant women. Future research should pay more attention to the effects of yoga on different stages of pregnancy and different groups of pregnant women. It is recommended that more trials be devoted to unveil the effects of yoga on childbirth and fetus. In addition, our recommendations allow researchers and yoga practitioners to make standardized programs that are suited for many pregnancy women, and make yoga exercise prescriptions for different groups of pregnancy women.

\section{Acknowledgements}

The present review was supported by Science and Technology Project of Hubei Province Education Department (Q20191305), Social Science Fund of Yangtze University (2019csy06), the Open Project of the Innovation Base for Cultivating Sport Doctoral Students' Academic Literacy (JDTY2019A04), the National Natural Science Foundation of China (31700736), China Scholarship Council (201908420102), Hubei Medical Youth Tip-Top Talent, Leading Talent Program of Yangtze Talent Project.

\section{Conflicts of Interest}

The authors declare no conflicts of interest regarding the publication of this paper.

\section{References}

[1] Sharma, M. and Branscum, P. (2015) Yoga Interventions in Pregnancy: A Qualitative Review. The Journal of Alternative and Complementary Medicine, 21, 208-216. https://doi.org/10.1089/acm.2014.0033

[2] Orr, S.T., Reiter, J.P., Blazer, D.G. and James, S.A. (2007) Maternal Prenatal Pregnancy-Related Anxiety and Spontaneous Preterm Birth in Baltimore, Maryland. Psychosomatic Medicine, 69, 566-570. https://doi.org/10.1097/PSY.0b013e3180cac25d

[3] Saunders, T.A., Lobel, M., Veloso, C. and Meyer, B.A. (2009) Prenatal Maternal Stress Is Associated with Delivery Analgesia and Unplanned Cesareans. Journal of Psychosomatic Obstetrics \& Gynecology, 27, 141-146. https://doi.org/10.1080/01674820500420637

[4] Beddoe, A.E. and Lee, K.A. (2008) Mind-Body Interventions during Pregnancy. Journal of Obstetric, Gynecologic, and Neonatal Nursing, 37, 165-175.

https://doi.org/10.1111/j.1552-6909.2008.00218.x 
[5] Toosi, M., Akbarzadeh, M. and Ghaemi, Z. (2017) The Effect of Relaxation on Mother's Anxiety and Maternal-Fetal Attachment in Primiparous IVF Mothers. Journal of the National Medical Association, 109, 164-171. https://doi.org/10.1016/j.jnma.2017.03.002

[6] Liu, Y.H., Lee, C.S., Yu, C.H. and Chen, C.H. (2016) Effects of Music Listening on Stress, Anxiety, and Sleep Quality for Sleep-Disturbed Pregnant Women. Women \& Health, 56, 296-311. https://doi.org/10.1080/03630242.2015.1088116

[7] Field, T. (2017) Prenatal Depression Risk Factors, Developmental Effects and Interventions: A Review. Journal of Pregnancy and Child Health, 4, pii: 301. https://doi.org/10.4172/2376-127X.1000301

[8] Ji, E.S. and Han, H.-R. (2010) The Effects of Qi Exercise on Maternal/Fetal Interaction and Maternal Well-Being during Pregnancy. Journal of Obstetric, Gynecologic \& Neonatal Nursing, 39, 310-318. https://doi.org/10.1111/j.1552-6909.2010.01135.x

[9] Wang, X., Li, P., Pan, C., Dai, L., Wu, Y., et al. (2019) The Effect of Mind-Body Therapies on Insomnia: A Systematic Review and Meta-Analysis. Evidence-Based Complementary and Alternative Medicine, 2019, Article ID: 9359807. https://doi.org/10.1155/2019/9359807

[10] Babbar, S., Parks-Savage, A.C. and Chauhan, S.P. (2012) Yoga during Pregnancy: A Review. American Journal of Perinatology, 29, 459-464. https://doi.org/10.1055/s-0032-1304828

[11] Field, T. (2011) Yoga Clinical Research Review. Complementary Therapies in Clinical Practice, 17, 1-8. https://doi.org/10.1016/j.ctcp.2010.09.007

[12] Wren, A.A., Wright, M.A., Carson, J.W. and Keefe, F.J. (2011) Yoga for Persistent Pain: New Findings and Directions for an Ancient Practice. Pain, 152, 477-480. https://doi.org/10.1016/j.pain.2010.11.017

[13] Jayashree, R., Malini, A., Rakhshani, A., Nagendra, H., Gunasheela, S., et al. (2013) Effect of the Integrated Approach of Yoga Therapy on Platelet Count and Uric Acid in Pregnancy: A Multicenter Stratified Randomized Single-Blind Study. International Journal of Yoga, 6, 39-46. https://doi.org/10.4103/0973-6131.105945

[14] Sengupta, P. (2012) Health Impacts of Yoga and Pranayama: A State-of-the-Art Review. International Journal of Preventive Medicine, 3, 444.

[15] Narendran, S., Nagarathna, R., Narendran, V., Gunasheela, S. and Nagendra, H.R.R. (2005) Efficacy of Yoga on Pregnancy Outcome. Journal of Alternative \& Complementary Medicine, 11, 237-244. https://doi.org/10.1089/acm.2005.11.237

[16] Satyapriya, M., Nagendra, H.R., Nagarathna, R. and Padmalatha, V. (2009) Effect of Integrated Yoga on Stress and Heart Rate Variability in Pregnant Women. International Journal of Gynaecology and Obstetrics. The Official Organ of the International Federation of Gynaecology and Obstetrics, 104, 218-222.

https://doi.org/10.1016/j.ijgo.2008.11.013

[17] Chuntharapat, S., Petpichetchian, W. and Hatthakit, U. (2008) Yoga during Pregnancy: Effects on Maternal Comfort, Labor Pain and Birth Outcomes. Complementary Therapies in Clinical Practice, 14, 105-115. https://doi.org/10.1016/j.ctcp.2007.12.007

[18] Gutke, A., Boissonnault, J., Brook, G. and Stuge, B. (2018) The Severity and Impact of Pelvic Girdle Pain and Low-Back Pain in Pregnancy: A Multinational Study. Journal of Women's Health, 27, 510-517. https://doi.org/10.1089/jwh.2017.6342

[19] Javnbakht, M., Hejazi Kenari, R. and Ghasemi, M. (2009) Effects of Yoga on Depression and Anxiety of Women. Complementary Therapies in Clinical Practice, 15, 102-104. https://doi.org/10.1016/j.ctcp.2009.01.003 
[20] Sathyaprabha, T.N., Satishchandra, P., Pradhan, C., Sinha, S., Kaveri, B., et al. (2008) Modulation of Cardiac Autonomic Balance with Adjuvant Yoga Therapy in Patients with Refractory Epilepsy. Epilepsy \& Behavior, 12, 245-252.

https://doi.org/10.1016/j.yebeh.2007.09.006

[21] Buttner, M.M., Brock, R.L., O'Hara, M.W. and Stuart, S. (2015) Efficacy of Yoga for Depressed Postpartum Women: A Randomized Controlled Trial. Complementary Therapies in Clinical Practice, 21, 94-100. https://doi.org/10.1016/j.ctcp.2015.03.003

[22] Davis, K., Goodman, S.H., Leiferman, J., Taylor, M. and Dimidjian, S. (2015) A Randomized Controlled Trial of Yoga for Pregnant Women with Symptoms of Depression and Anxiety. Complementary Therapies in Clinical Practice, 21, 166-172. https://doi.org/10.1016/j.ctcp.2015.06.005

[23] Uebelacker, L.A., Battle, C.L., Sutton, K.A., Magee, S.R. and Miller, I.W. (2015) A Pilot Randomized Controlled Trial Comparing Prenatal Yoga to Perinatal Health Education for Antenatal Depression. Archives of Women's Mental Health, 19, 543-547. https://doi.org/10.1007/s00737-015-0571-7

[24] Holden, S.C., Manor, B., Zhou, J., Zera, C., Davis, R.B., et al. (2019) Prenatal Yoga for Back Pain, Balance, and Maternal Wellness: A Randomized, Controlled Pilot Study. Global Advances in Health and Medicine, 8, Article ID: 216495611987098. https://doi.org/10.1177/2164956119870984

[25] Kusaka, M., Matsuzaki, M., Shiraishi, M. and Haruna, M. (2016) Immediate Stress Reduction Effects of Yoga during Pregnancy: One Group Pre-Post Test. Women and Birth: Journal of the Australian College of Midwives, 29, e82-e88. https://doi.org/10.1016/j.wombi.2016.04.003

[26] Matsuzaki, M., Kusaka, M., Sugimoto, T., Shiraishi, M., Kobayashi, R., et al. (2018) The Effects of a Yoga Exercise and Nutritional Guidance Program on Pregnancy Outcomes among Healthy Pregnant Japanese Women: A Study Protocol for a Randomized Controlled Trial. Journal of Alternative and Complementary Medicine, 24, 603-610. https://doi.org/10.1089/acm.2017.0119

[27] Hayase, M. and Shimada, M. (2018) Effects of Maternity Yoga on the Autonomic Nervous System during Pregnancy. The Journal of Obstetrics and Gynaecology Research, 44, 1887-1895. https://doi.org/10.1111/jog.13729

[28] Rakhshani, A., Nagarathna, R., Mhaskar, R., Mhaskar, A., Thomas, A., et al. (2015) Effects of Yoga on Utero-Fetal-Placental Circulation in High-Risk Pregnancy: A Randomized Controlled Trial. Advances in Preventive Medicine, 2015, Article ID: 373041. https://doi.org/10.1155/2015/373041

[29] Chen, P.J., Yang, L., Chou, C.C., Li, C.C., Chang, Y.C., et al. (2017) Effects of Prenatal Yoga on Women's Stress and Immune Function across Pregnancy: A Randomized Controlled Trial. Complementary Therapies in Medicine, 31, 109-117. https://doi.org/10.1016/j.ctim.2017.03.003

[30] Timlin, D. and Simpson, E.E. (2017) A Preliminary Randomised Control Trial of the Effects of Dru Yoga on Psychological Well-Being in Northern Irish First Time Mothers. Midwifery, 46, 29-36. https://doi.org/10.1016/j.midw.2017.01.005

[31] Akarsu, R.H. and Rathfisch, G. (2018) The Effect of Pregnancy Yoga on the Pregnant's Psychosocial Health and Prenatal Attachment. Indian Journal of Tradition Knowledge, 17, 732-740.

[32] Jahdi, F., Sheikhan, F., Haghani, H., Sharifi, B., Ghaseminejad, A., et al. (2017) Yoga during Pregnancy: The Effects on Labor Pain and Delivery Outcomes (A Randomized Controlled Trial). Complementary Therapies in Clinical Practice, 27, 1-4. https://doi.org/10.1016/j.ctcp.2016.12.002

[33] Mohyadin, E., Ghorashi, Z. and Molamomanaei, Z. (2020) The Effect of Practicing 
Yoga during Pregnancy on Labor Stages Length, Anxiety and Pain: A Randomized Controlled Trial. Journal of Complementary \& Integrative Medicine. https://doi.org/10.1515/jcim-2019-0291

[34] Novelia, S., Sitanggang, T.W. and Yulianti, A. (2018) Effects of Yoga Relaxation on Anxiety Levels among Pregnant Women. Nurse Media Journal of Nursing, 8, 86-95. https://doi.org/10.14710/nmjn.v8i2.19111

[35] Wei, C.W., Wu, Y.C., Chen, P.Y., Chen, P.E., Chi, C.C., et al. (2019) Effectiveness of Yoga Interventions in Breast Cancer-Related Lymphedema: A Systematic Review. Complementary Therapies in Clinical Practice, 36, 49-55.

https://doi.org/10.1016/j.ctcp.2019.05.004

[36] Ross, A., Friedmann, E., Bevans, M. and Thomas, S. (2013) National Survey of Yoga Practitioners: Mental and Physical Health Benefits. Complementary Therapies in Medicine, 21, 313-323. https://doi.org/10.1016/j.ctim.2013.04.001

[37] Kinser, P., Jallo, N., Thacker, L., Aubry, C. and Masho, S. (2019) Enhancing Accessibility of Physical Activity during Pregnancy: A Pilot Study on Women's Experiences with Integrating Yoga into Group Prenatal Care. Health Services Research and Managerial Epidemiology, 6, Article ID: 2333392819834886.

https://doi.org/10.1177/2333392819834886

[38] Previti, G., Pawlby, S., Chowdhury, S., Aguglia, E. and Pariante, C.M. (2014) Neurodevelopmental Outcome for Offspring of Women Treated for Antenatal Depression: A Systematic Review. Archives of Women's Mental Health, 17, 471-483. https://doi.org/10.1007/s00737-014-0457-0

[39] Gong, H., Ni, C., Shen, X., Wu, T. and Jiang, C. (2015) Yoga for Prenatal Depression: A Systematic Review and Meta-Analysis. BMC Psychiatry, 15, 14. https://doi.org/10.1186/s12888-015-0393-1

[40] Battle, C.L., Uebelacker, L.A., Howard, M. and Castaneda, M. (2010) Prenatal Yoga and Depression during Pregnancy. Birth, 37, 353-354.

https://doi.org/10.1111/j.1523-536X.2010.00435 1.x

[41] Jiang, Q., Wu, Z., Zhou, L., Dunlop, J. and Chen, P. (2015) Effects of Yoga Intervention during Pregnancy: A Review for Current Status. American Journal of Perinatology, 32, 503-514. https://doi.org/10.1055/s-0034-1396701

[42] Nater, U.M. and Rohleder, N. (2009) Salivary Alpha-Amylase as a Non-Invasive Biomarker for the Sympathetic Nervous System: Current State of Research. Psychoneuroendocrinology, 34, 486-496. https://doi.org/10.1016/j.psyneuen.2009.01.014

[43] Chao, A.-S., Chao, A., Wang, T.-H., Chang, Y.-C., Peng, H.-H., et al. (2007) Pain Relief by Applying Transcutaneous Electrical Nerve Stimulation (TENS) on Acupuncture Points during the First Stage of Labor: A Randomized Double-Blind Placebo-Controlled Trial. Pain, 127, 214-220. https://doi.org/10.1016/j.pain.2006.08.016

[44] Sun, Y.C., Hung, Y.C., Chang, Y. and Kuo, S.C. (2010) Effects of a Prenatal Yoga Programme on the Discomforts of Pregnancy and Maternal Childbirth Self-Efficacy in Taiwan. Midwifery, 26, e31-e36. https://doi.org/10.1016/j.midw.2009.01.005

[45] Field, T. (2012) Yoga and Social Support Reduce Prenatal Depression, Anxiety and Cortisol. Journal of Yoga \& Physical Therapy, 2, 397-403.

https://doi.org/10.4172/2157-7595.1000124

[46] Pont, A.V., Rosiyana, N.M., Pratiwi, V., Enggar, N., et al. (2019) The Effect of Prenatal Yoga in Reducing Pregnancy Complaints. Indian Journal of Public Health Research \& Development, 10, 1218-1222. https://doi.org/10.5958/0976-5506.2019.02061.8 